\title{
Prodrug Strategies for Paclitaxel
}

\author{
Ziyuan Meng ${ }^{1,2, \dagger}$, Quanxia Lv ${ }^{1,2,+}$, Jun Lu ${ }^{1}$, Houzong Yao ${ }^{1}$, Xiaoqing Lv ${ }^{2}$, Feng Jiang ${ }^{1,2,3, *}$, \\ Aiping $\mathrm{Lu}{ }^{1,2, *}$ and Ge Zhang ${ }^{1,2, *}$ \\ 1 Institution for Advancing Translational Medicine in Bone \& Joint Diseases, School of Chinese Medicine, \\ Hong Kong Baptist University, Hong Kong 999077, China; 15484572@life.hkbu.edu.hk (Z.M.); \\ lvquanxia@163.com (Q.L.); ljaaa111@163.com (J.L.); yaohouzong@163.com (H.Y.) \\ 2 Research Group of Precision Medicine and Innovative Drug, \\ HKBU (Hong Kong Baptist University) (Haimen) Institute of Science and Technology, \\ Haimen 226100, China; lxqd1@126.com \\ 3 The State Key Laboratory Base of Novel Functional Materials and Preparation Science, \\ Faculty of Materials Science and Chemical Engineering, Ningbo University, Ningbo 315211, China \\ * Correspondence: jiangfenghz@163.com (F.J.); aipinglu@hkbu.edu.hk (A.L.); zhangge@hkbu.edu.hk (G.Z.); \\ Tel.: +86-513-8210-6970 (F.J.); +852-3411-2456 (A.L.); +852-3411-2958 (G.Z.) \\ + These authors contributed equally to this work.
}

Academic Editor: Katalin Prokai-Tatrai

Received: 23 March 2016; Accepted: 11 May 2016; Published: 23 May 2016

\begin{abstract}
Paclitaxel is an anti-tumor agent with remarkable anti-tumor activity and wide clinical uses. However, it is also faced with various challenges especially for its poor water solubility and low selectivity for the target. To overcome these disadvantages of paclitaxel, approaches using small molecule modifications and macromolecule modifications have been developed by many research groups from all over the world. In this review, we discuss the different strategies especially prodrug strategies that are currently used to make paclitaxel more effective.
\end{abstract}

Keywords: paclitaxel; poor water solubility; low selectivity; prodrug

\section{Introduction}

Paclitaxel (Figure 1) was isolated from Taxus brevifolia and its anticancer activity first reported in 1971 [1]. Additionally, it was approved as a kind of microtubule stabilizing agent in 1992. As an anticancer drug, paclitaxel can promote tubulin polymerization and stabilize microtubules from depolymerizing [2]. These procedures are relevant to special regions on tubulin including H6-H7 and the M-loop [3]. Paclitaxel is also able to interact with tubulin assemblages at low temperatures, as well as without GTP or microtubule-associated proteins [4]. The binding affinity of paclitaxel and tubulin depends on the nucleotide content of tubulin [5]. Due to this unique anticancer mechanism, paclitaxel has aroused much interest for further development. Besides its anticancer activity, paclitaxel can exert a variety of positive influences on the immune system [6], and play a potential role in treating neurodegenerative diseases as well as inhibiting botulinum neurotoxin $[7,8]$.

Although paclitaxel is effective for various human diseases, it is also faced with limitations: first, paclitaxel has extremely poor water solubility and it needs a relatively higher dose to take effect compared to other anticancer drugs. For these reasons, it is always administered with ethanol and Cremophor EL as vehicles to increase its water solubility, which may cause severe hypersensitivity in patients. Hence, to avoid this hypersensitivity and obtain better clinical use of paclitaxel, developing a new co-solvent [9-11] and improving the formulation for paclitaxel delivery systems has become important [12]. In recent years, outstanding drug delivery systems for paclitaxel have been developed, and different carriers have been employed, such as cubosomes [13], $\beta$-cyclodextrins [14,15], gold 
microplate [16], gold nanorod [17], lipid vesicles [18], microparticles [19], nanoparticles [20,21], micelles [22-26], and liposomes [27].

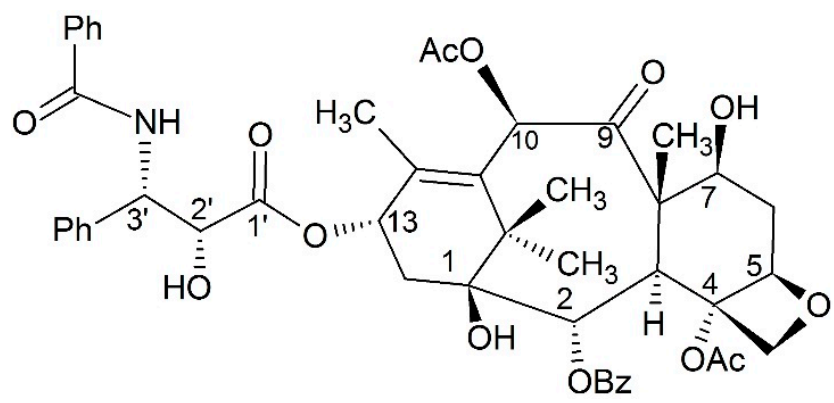

Figure 1. The structure of paclitaxel.

Other than its low water solubility, paclitaxel is also faced with multiple drug resistance like other anti-cancer agents. Specific excipients or administered in combination with other drugs were used to solve this limitation [28]. Also many formulations have been under clinical trials or investigation [29]. One research showed that better efficacy of paclitaxel could be obtained by prescribing with carboplatin which could produce a synergistic effect [30]. In the same strain, with the development of anticancer agents for paclitaxel resistant cancer cells, new chances for paclitaxel's combination have been provided [31]. In recent years, paclitaxel has also been delivered with microRNA, shRNA and siRNA to get better therapeutic effects [32-34]. Furthermore, it also shows dose limiting side effects, which are common to other cytotoxic agents [35].

In addition to developing better formulation for paclitaxel, there were mainly two ways to achieve more efficient modified paclitaxel. One was to synthesize various paclitaxel analogs. These strategies included hybridizing paclitaxel with other chemicals, blocking paclitaxel's metabolic sites, locking the binding conformation by bridging converts or directly modifying its structure [36-40]. These paclitaxel analogs were more efficient with regard to water solubility and anticancer activity [41]. The other way was to transfer paclitaxel into a prodrug which can release free paclitaxel after administration. Through this way, the shortcomings of paclitaxel as described above could be largely overcome. These prodrugs included small molecule prodrugs and macro molecule prodrugs. Most of the small molecule prodrugs were designed to overcome paclitaxel's low water solubility. For the macro molecule prodrugs, paclitaxel was conjugated to polymers or protein. This strategy could commonly increase the targeting ability of paclitaxel by enhanced permeability and retention effects (EPR) as for other macro molecule prodrugs [42]. Herein, various prodrug strategies that have been currently used to make paclitaxel more effective are presented.

\section{Structure and Activity Relationships}

As for prodrug strategy, understanding the structure and activity relationship is the first step. Pioneer work showed that the central part of paclitaxel is rigid to a change in structure, while its side chain tail can be flexible [43]. In the central part of paclitaxel, the 1-OH and 2-benzoyloxy are important to paclitaxel's anti-cancer activity [44]. Additionally in the flexible side chain, the activity of paclitaxel can be influenced by the stereochemistry of $\mathrm{C2}^{\prime}$ and $\mathrm{C} 3^{\prime}$ [45]. Furthermore, another work postulated $\mathrm{C2}^{\prime}-\mathrm{OH}$ to be the bonding site of paclitaxel to tubulin [46]. Therefore, it was proposed to be the most important functional group in the region of the $\mathrm{C}-13$ side chain which is a basic component for paclitaxel $[47,48]$. Thus, early development mainly focused on the C2'-position and C3'-position. Although C-7 to C-10 of paclitaxel does not interact with tubulin directly, it had been postulated that changes of this region might affect its bonding affinity to P-glycoprotein which is responsible for the MDR phenotype [49]. 
Due to its complicated structure, paclitaxel can be modified at different positions to obtain paclitaxel analogs, such as 2'-OH [50,51], 3'-position [49,52], C-2 position [53], C-4 position [54-56], C-7 position [49], C-10 position [57], C-13 position [58] or D-ring [59]. The macrocyclic paclitaxel analog had also been synthesized according to the structure activity relationship [60]. However, for prodrug strategy, $\mathrm{C2}$ '-OH has been the most commonly adopted, as it may be the binding site of paclitaxel to tubulin. At the same time $\mathrm{C} 7-\mathrm{OH}$ has also been adopted by some other groups.

\section{Small Molecule Paclitaxel Prodrug}

In this part, approaches to build up of small molecule paclitaxel prodrugs are introduced, including non-targeting prodrugs and targeting prodrugs.

\subsection{Non-Targeting Modification}

\subsubsection{Hydrophilic Modification}

As paclitaxel's anticancer mechanism became unfolded, making it more water soluble or bio-active was crucial before its clinical use. Two opposite approaches were adopted by different groups. One was to make paclitaxel prodrug more water soluble directly in order to get better bio-compatibility. The other way was to make paclitaxel more hydrophobic which was suitable for long half-life hydrophobic formulation. The hydrophobic modification will be introduced in the next section. Both ways were feasible for developing paclitaxel prodrugs.

\section{Skeletal Migration}

Hayashi and co-workers developed the ammonium salt of isopaclitaxel with good water solubility (Figure 2). After administrating, the isopaclitaxel could $\mathrm{pH}$ dependently form paclitaxel via $\mathrm{O}-\mathrm{N}$ acyl migration without auxiliary and byproduct. The isopaclitaxel has great advantages with respect to toxicology and medical economics [61]. However, the results of in vivo study are still missing, thus experiments need to be performed to confirm its efficacy.

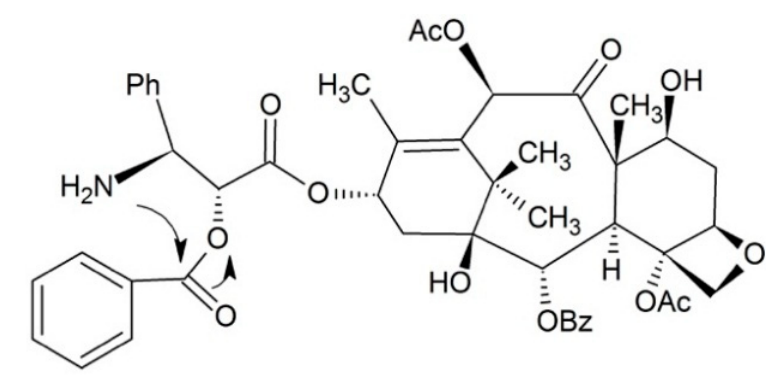

Figure 2. Skeletal migration approach for paclitaxel prodrug.

\section{Phosphate Esters}

In drug design, forming phosphate esters is a common strategy making the drug more soluble in water. In addition to good water solubility, the phosphate ester can also be a site of the substrate for alkaline phosphatases, this property enables the paclitaxel prodrug to have a fast release of the parent drug. Some simple phosphonooxymethyl ethers of paclitaxel were synthesized by introducing phosphate moieties to $2^{\prime}-\mathrm{OH}$ and $7-\mathrm{OH}$. The resulting prodrug had greatly improved water solubility and could release the free paclitaxel upon incubation with plasma and alkaline phosphatase [62]. In order to release free paclitaxel easier, Ueda and co-workers [63] introduced phosphate groups to 7-OH of 2'-ethoxycarbonypaclitaxel. In their design, the "trimethyl lock" was used to accelerate the release of the parent drug as a substrate of alkaline phosphatases (Figure 3). The water solubility is $2.5-5 \mathrm{mg} / \mathrm{mL}$, and some of the compounds exhibit comparable in vivo cytotoxicity in the M109 murine tumor model. 


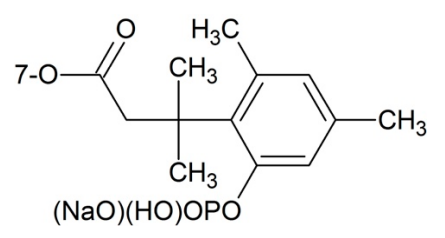

Figure 3. Trimethyl lock strategy.

\section{Others}

Besides phosphate esters, there were other methods to improve the water solubility of paclitaxel. Such as, Damen et al. [64] synthesized two paclitaxel esters of malic acid at 2'-OH and 7-OH respectively. The resulting prodrugs were stable in plasma, and exhibited improved water solubility, antitumor activity, and less cytoxicity. Niethammer et al. [65] found when 7-OH was blocked by a pH-dependent cleavable dihydroxypropyl side chain, the afforded prodrug could achieve equal anti-tumor activity but was 50-fold more water soluble compared to free paclitaxel (Figure 4).

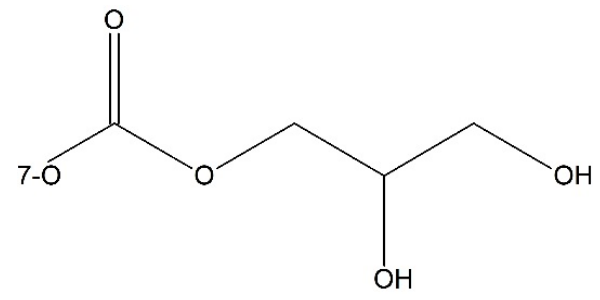

Figure 4. The pH-dependent cleavable dihydroxypropyl side chain.

\subsubsection{Hydrophobic Modification}

The other way for the small molecule non-targeting paclitaxel prodrug was to make paclitaxel more hydrophobic by linking a hydrophobic moiety at the 2'-OH position. These hydrophobic paclitaxel prodrugs were more suitable for a nanoparticle delivery system with a longer half life in circulation [66].

\section{Silicate Esters}

In order to achieve a wider water solubility range of the paclitaxel prodrug, $2^{\prime}-\mathrm{OH}$ was silicated with different alkyl groups. By changing the alkyl group, the water solubility could shift to a proper range for formulation [67]. Han and co-workers synthesized silicate derivatives of paclitaxel as prodrugs. In their study, the alkyl group in the silicate derivatives was chosen to generate prodrugs with greater hydrophobicity for preparing nanoparticles, and then a formulation with maximum loading capacity of $75 \mathrm{wt} \%$ of prodrug and greater in vitro efficacy was prescribed. Table 1 shows cLogP and $t_{1 / 2}$ of silicated paclitaxel prodrugs with different alkyl groups [68].

Table 1. cLogP and $\mathrm{t}_{1 / 2}$ of silicated paclitaxel prodrugs with different alkyl groups.

\begin{tabular}{cccc}
\hline $\mathbf{2}^{\prime}-\mathbf{O}$ & $\mathbf{7 - O}$ & $\mathbf{c L o g} \mathbf{P}$ & $\mathbf{T}_{\mathbf{1 / 2}}$ (min) \\
\hline $\mathrm{H}$ & $\mathrm{H}$ & 3.2 & $\mathrm{~N} / \mathrm{A}$ \\
$\mathrm{Si}(\mathrm{OEt})_{3}$ & $\mathrm{H}$ & 5.0 & 3.7 \\
$\mathrm{Si}(\mathrm{O} n-\mathrm{Oct})_{3}$ & $\mathrm{H}$ & 7.7 & 12 \\
$\mathrm{Si}(\mathrm{O} i-\mathrm{Pr})$ & $\mathrm{H}$ & 5.6 & 120 \\
$\mathrm{Si}(\mathrm{O} \text {-Bu })_{2}(\mathrm{OEt})$ & $\mathrm{H}$ & 5.8 & 12,000 \\
$\mathrm{Si}(\mathrm{Omenthyl})_{3}$ & $\mathrm{H}$ & 7.4 & 69,000 \\
$\mathrm{H}$ & $\mathrm{Si}(\mathrm{OEt})_{3}$ & 5.1 & 30 \\
$\mathrm{H}$ & $\mathrm{Si}(\mathrm{O} n-\mathrm{Oct})_{3}$ & 7.8 & 150 \\
$\mathrm{Si}(\mathrm{OEt})_{3}$ & $\mathrm{Si}(\mathrm{OEt})_{3}$ & 6.3 & $4.6\left(2^{\prime}-\mathrm{O}\right)$ \\
& & & $33(7-\mathrm{O})$ \\
\hline
\end{tabular}


Squalenoylation Technology

Other than silicate esters, squalenoylation technology has also been developed for delivering poorly water soluble therapeutic agents. When a hydrophilic polyethylene glycol (PEG) linker is introduced between hydrophobic paclitaxel and squalene, the water solubility can be adjusted by selecting the most suitable length of the PEG linker and squalene moiety. A series of paclitaxel prodrugs was synthesized by Dosio and co-workers [69]. All the prodrugs can self-assemble into nanoparticles in low concentration and are stable in water for several weeks. Preliminary biological studies showed these squalenoyl-paclitaxel nanoassemblies can induce the HT-29 and KB-31 cells' microtubule bundles from forming, and it also exhibited notable antitumor activity on a lung tumor cell line. Overall this technology has potential for delivering a poorly soluble drug.

\subsubsection{Mutual Drugs}

Mutual prodrug strategy can contribute a lot to obtain paclitaxel prodrugs with higher anti-cancer efficiency and increased water solubility. Wittman et al. [70] reported that the combination of paclitaxel with other antitumor agents could afford improved cytotoxicity to MDR cell lines. In the study, a series of chlorambucil-paclitaxel prodrugs were synthesized, and the compound exhibited in Figure 5 was demonstrated to have vigorous antitumor activity in vivo, based on M109 murine models and paclitaxel resistant M109/taxlR models.

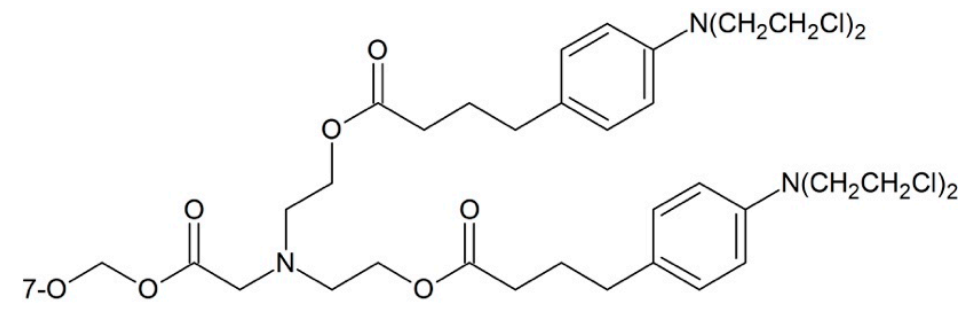

Figure 5. Chlorambucil-paclitaxel prodrug.

Muramyl dipeptide (MDP) which can elicit human immunological responses is the minimal structure of Gram-positive and the Gram-negative bacteria's cell walls. Paclitaxel prodrugs containing MDP or its analog motifs can elicit human immunological responses, and thus achieve a synergistic anticancer effect. This strategy can combine immunotherapy and chemotherapy together in curing cancer. The dipeptide-paclitaxel prodrugs in which the dipeptide was conjugated to the $3^{\prime}$-amino group, $2^{\prime}$ - and 7-hydroxyl group of the paclitaxel were synthesized respectively (Figure 6). Among them, the $2^{\prime}-\mathrm{OH}$ prodrug was around 200 times more water-soluble than paclitaxel [71]. However, further researches showed that it was not powerful in antitumor activity. Thus, further chemical modification of this prodrug was conducted by the group for better efficacy [72].

Caron and co-workers linked paclitaxel and gemcitabine together via a short polyisoprenoyl spacer. This series of bolaform polyisoprenoyl paclitaxel and gemcitabine prodrug can form nanoassemblies with a diameter of 100-200 nm due to the property of the spacer. These nanodevices with high drug loading rate showed improved in vitro activities on several human and murine cancer cell lines compared to those nanoassemblies of the squalenoyl drugs solely or in combination. Thus, this preparation method is potent for nanoparticle mediated combination therapy [73].

Besides enhancing antitumor activity, the antistenotic profile of paclitaxel can also be increased via mutual drug strategy. An early attempt was conducted by Vrudhula and co-workers [74]. They synthesized the captopril-paclitaxel mutual prodrug, and the antistenotic profile was obviously increased. Recently paclitaxel was conjugated to polyisobutylene for controlled release from vascular stent coating, the results showed that this coated stent was potent for clinical use [75]. In order to achieve better therapeutic effects of paclitaxel coated stents, adamantine nitrosothiol was introduced 
at the 7-position as a nitric oxide donor (Figure 7). Stents coated with this modified paclitaxel were $34 \%$ better than paclitaxel coated stents, and $41 \%$ better than polymer coated stents [76].<smiles>CC(=O)CCC(=O)NCCCCC(NC(=O)CCC(NC(=O)[C@H](C)NC(=O)C(C)OC1[C@H](O)[C@H](CO)O[C@H](Cc2ccccc2)[C@H]1O)C(N)=O)C(=O)O</smiles>

Figure 6. Muramyl dipeptide-paclitaxel prodrug.<smiles>CC(C)(C[14CH3])[N+](=O)[O-]</smiles>

Figure 7. Paclitaxel prodrug containing nitric oxide donor.

\subsubsection{Dipeptide Prodrugs}

As mentioned above, paclitaxel shows dose limiting side effects [35]. In order to reduce such side effects, Dubowchik et al. [77] conjugated a cathepsin-B sensitive dipeptide (Phe-Lys) to both the $2^{\prime}-\mathrm{OH}$ and $7-\mathrm{OH}$ of the paclitaxel and a self-immolative PABC ( $p$-aminobenzyloxycarbonyl) linker was employed to avoid steric interference between the dipeptide and paclitaxel. They found the resulting prodrugs were stable in plasma and could release the paclitaxel when internalized by tumor cells. In addition, the prodrug in which the modified group was the 7-OH showed a longer half-life of $66 \mathrm{~min}$ in rat liver lysosome than the $2^{\prime}-\mathrm{OH}$ of $19 \mathrm{~min}$. Although the 7-OH showed a shorter half-life of $40 \mathrm{~min}$ in cathepsin B solution, the $2^{\prime}-\mathrm{OH}$ modification was $9 \mathrm{~h}$.

\subsubsection{Others}

Paclitaxel could bind not only to tubulin but also to P-glycoprotein [78]. A paclitaxel prodrug with succinate at the C10 position showed low affinity to P-glycoprotein which could enable the paclitaxel analog to pass through the blood-brain-barrier. In this way, the paclitaxel concentration is enhanced in the brain about 3-fold. Meanwhile cytotoxic research showed the prodrug could retain comparable efficacy towards the breast cancer line MCF7 with an IC $_{50}$ of $35.7 \mathrm{~nm}$ compared to paclitaxel's IC $_{50}$ on this cell line which is $1.8 \mathrm{~nm}$ [79]. 
Photodynamic therapy (PDT) is a type of method for treating cancer. After a sensitizer is administered, the pathological area is exposed to visible light. The beam of light can activate a sensitizer to release a cytotoxic free radical or singlet oxygen. Skwarczynski and co-workers [80] first synthesized photo responsive paclitaxel by introducing $7-N, N$-diethylamino-4-hydroxymethyl coumarin (DECM) as a photolabile group to 2'-benzoyl-paclitaxel which could increase paclitaxel's water solubility by transforming it into chloride and be activated at $430.6 \mathrm{~nm}$ without decomposition (Figure 8). After activation by light, the cleavage of the carbamate induces $\mathrm{O}-\mathrm{N}$ acyl migration to end up with paclitaxel. Noguchi and co-workers [81] also synthesized a coumarin-based high water soluble paclitaxel prodrug, which could release the parent drug at $365 \mathrm{~nm}$ UV light.<smiles>CCN(CC)c1ccc2c(COC(=O)NC)cc(=O)oc2c1</smiles>

Figure 8. Photo responsive paclitaxel.

Besides the above, the DHA-Paclitaxel prodrug is a very important compound. This prodrug strategy is realized by the conjugate DHA molecule to 2'-OH and is tested in the M109 mouse tumor model. Results show tumor AUCs for DHA-paclitaxel are 61-fold higher at equitoxic doses and 8-fold higher at equimolar doses than palitaxel [82].

\subsection{Targeting Modification}

\subsubsection{Targeting Tumor Overexpressed Enzymes}

Tumor tissues are different from normal tissues in various aspects. One difference is that some enzymes are over expressed in tumor tissues. By employing a tumor overexpressed enzymes recognition motif paclitaxel prodrugs can show selective cytotoxicity towards tumor tissues.

Targeting $\beta$-D-Glucuronidase

$\beta$-D-Glucuronidase is a kind of extracellular enzyme in necrotic tumors. Prodrugs in which the paclitaxel is modified with $\beta$-glucuronide can increase the selectivity and the water solubility of paclitaxel. By attaching $\beta$-glucuronide and a self-immolative spacer to the 2 -position of the paclitaxel, Alaoui et al. [83] successfully developed a strategy to obtain a plasma stable and enzyme cleavable prodrug which could be used for prodrug monotherapy (PMT) and antibody directed enzyme prodrug therapy (ADEPT) (Figure 9). The $\mathrm{IC}_{50}$ of this compound is $11.3 \mathrm{~nm}$ compared to free paclitaxel $0.16 \mathrm{~nm}$ on HT-29, but further in vivo study needs to be carried out. 
<smiles>CC(=O)OCCN(C)C(=O)OCc1ccc(OC2O[C@H](C(=O)O)[C@@H](O)[C@H](O)[C@H]2O)c(N)c1</smiles>

Figure 9. Targeting $\beta$-D-glucuronidase prodrug.

Targeting Prostate-Specific Antigen (PSA)

Different peptide moieties can be recognized and decomposed by the different corresponding enzymes. When attached to peptide moieties, paclitaxel can obtain target ability. Elsadek and co-workers [84] designed and prepared EMC-Arg-Ser-Ser-Tyr-Tyr-Ser-Leu-PABC-paclitaxel (EMC: $\varepsilon$-maleimidocaproyl; PABC: $p$-aminobenzyloxycarbonyl) which contained a prostate-specific antigen (PSA) cleavable peptide site. EMC in the compound was an active moiety which enabled the conjugate to bind to albumin, and be retained by the vessels in the prostate. These properties made the conjugate promising for future development in curing prostate cancer. Kumar and co-workers [85] also synthesized paclitaxel prodrug targeting PSA by taking advantages of HSSKLQ (His-Ser-Ser-Lys-Leu-Gln) or SSKYQ (Ser-Ser-Lys-Tyr-Gln) peptides which could be cleaved by PSA. The peptides and the paclitaxel were linked with para-aminobenzyl alcohol (PABS) or ethylene diamine (EDA). Inducing these linkers resulted in an increased hydrolysis rate of the prodrug by PSA. The anti-cancer activities of these prodrugs were conducted on various cell lines, including CWR22Rv1 prostate cancer cell line. Among these prodrugs, the compound in which the peptide and the paclitaxel were linked with ethylene diamine was stable and could be efficiently converted into free paclitaxel that kills cancer cells in the presence of PSA (Figure 10).<smiles>COC(=O)N(C)CCNC(=O)[C@H](CCC(N)=O)NC(=O)C(Cc1ccc(O)cc1)NC(=O)[C@H](CCCCN)NC(=O)[C@H](CO)NC(=O)[C@H](CO)NC(=O)N1CCOCC1</smiles>

Figure 10. Targeting PSA (prostate-specific antigen) paclitaxel prodrug.

Besides targeting $\beta$-D-glucuronidase and targeting PSA paclitaxel prodrugs, targeting the plasmin prodrug of paclitaxel has also potential for future use [86]. 


\subsubsection{Targeting Transporters}

Facilitative glucose transporters (GLUTs) are a kinds of transporters which are responsible for uptaking glucose into cells. By attaching $2^{\prime}$-glucopyranose to the $2^{\prime}-\mathrm{OH}$ of the paclitaxel via succinic acid, Liu et al. [87] obtained a good paclitaxel analogue with high selectivity towards GLUTs. To further improve the water solubility of paclitaxel, Lin and co-workers [88] prepared a series of $2^{\prime}$-paclitaxel conjugates by employing the $2^{\prime}$-glucose or glucuronic acid motif. These prodrugs showed enhanced water solubility and great selectivity towards GLUTs which were overexpressed in tumor cells (Figure 11).

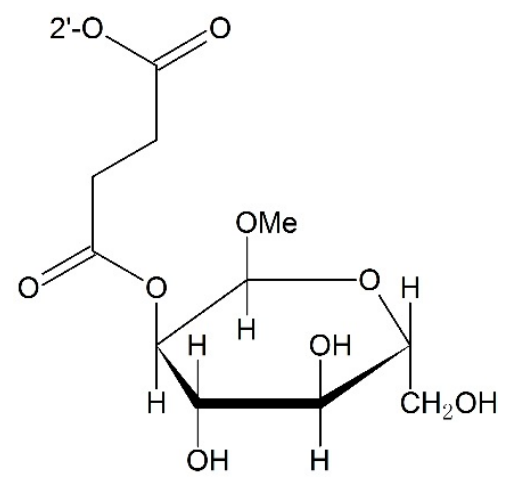

Figure 11. Targeting GLUTs (facilitative glucose transporters) prodrug.

\subsubsection{Targeting Hypoxia}

Hypoxia is a phenomenon of low oxygen concentration in tissues. In solid tumor, mild oxygen deficiency (hypoxia) or severe oxygen deficiency (anoxia) regions can be usually observed. In these parts, due to inefficient blood supply, drugs cannot reach their targets easily. In addition, hypoxic cells may also be resistant to both radiotherapy and conventional chemotherapy [89]. Hence, developing bioreductive (pro)drugs targeting hypoxia with low side effects is necessary. Damen et al. [35] first prepared a bioreductive paclitaxel prodrug by attaching the aromatic nitro and azido groups bioreductive trigger to $\mathrm{C}^{\prime}-\mathrm{OH}$. For blocking $\mathrm{C}^{\prime}-\mathrm{OH}$, lower side effects could be achieved. When reaching hypoxia regions, free paclitaxel was released after reduction of the nitro group and 1,6-elimination of a 4-amino or 4-hydroxylamino benzyloxycarbonyl moiety (Figure 12).<smiles>[14CH3]C(=O)OC/C=C/c1ccc([N+](=O)[O-])cc1</smiles>

Figure 12. Targeting hypoxia prodrug.

\subsubsection{Targeting Integrin}

Integrin is an important protein in promoting cell attachment and migration for tumor cells. Pilkinton and co-workers [90] synthesized a series of conjugates by linking paclitaxel to either cyclic AbaRGD (Azabicycloalkane-RGD) or AmproRGD (Aminoproline-RGD) integrin recognizing matrices with various linkers. The results showed these conjugates had satisfactory binding affinity towards the integrin, excellent cell sensitivity, and remarkable antitumor activity (Figure 13). Zhang et al. [91] also conjugated paclitaxel to cyclo-(Arg-Gly-Asp-D-Phe-Lys) (c[RGDfK]) for treating glioma tumor. In addition, the cyclo [DKP-RGD] peptidomimetics-paclitaxel conjugate and dimeric RGD peptide-paclitaxel conjugate also achieved a superior antitumor effect against the IGROV-1/Pt1 human ovarian carcinoma xenotransplanted in nude mice compared to paclitaxel $[92,93]$. 


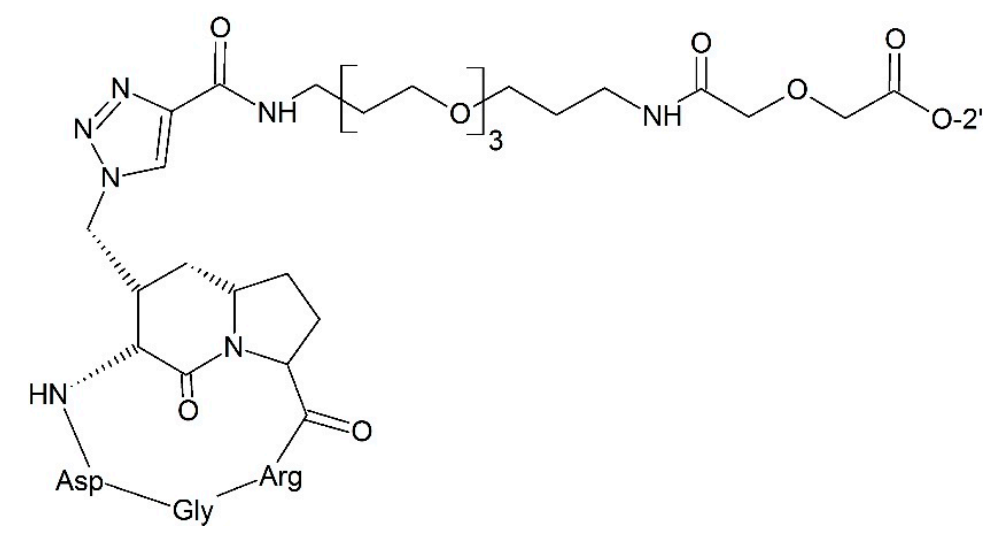

Figure 13. Targeting integrin prodrug.

\subsubsection{Targeting Receptors}

Folic receptor- $\alpha$ (FA- $\alpha)$ expresses little in normal cells and even not be detectable. Nevertheless, it is upregulated and can be detected in some kinds of cancer cells. Folic acid is the ligand of FA- $\alpha$ and therefore can target drugs to such kind of cancer cells with high expression of FA- $\alpha$. Shan et al. [94] synthesized multi-small molecule conjugations in which folic acid was conjugated to paclitaxel at the 2'-position via single amino acids (Arg or Glu). This resulting prodrug showed improved water solubility. Besides, this prodrug showed increased uptake by FR- $\alpha$ over expressing tumor cells (i.e., MCF-7, MDA-MB-231, and A549) when compared to normal HEK293 cells. This suggests the prodrugs have good anticancer activity and targeting ability.

Taking advantages of receptor bonding peptide is an efficient way for targeting delivery, Ndungu et al. [95] synthesized the conjugate in which the tissue factor binding peptide fVIIa was attached to paclitaxel at the $\mathrm{C} 2{ }^{\prime}$ or $\mathrm{C} 7$ position via a succinic acid linker. The conjugate showed better anti-cancer activity towards human head and neck squamous KB3-1 cells.

\subsubsection{Targeting Glutathione}

Many tumor cells contain a high concentration of glutathione which can be used to targeting delivery of the drug to tumor cells. Taking advantages of intracellular sulfhydryl-containing spices such as glutathione (GSH) or its thiolate anion $\mathrm{GS}^{-}$at a biological $\mathrm{pH}$ attacking the disulfide bond, Gund et al. [96] designed various prodrugs containing disulfide linker which showed better water solubility and anticancer activity than free paclitaxel (Figure 14).<smiles>[Z20]OC(=O)OCCSSCCN</smiles>

Figure 14. Targeting glutathione prodrug.

\subsubsection{Prodrugs for Antibody Directed Enzyme Prodrug Therapy (ADEPT)}

ADEPT is the strategy aiming to achieve selective toxicity to tumor cells meanwhile keeping normal cells undamaged from stand by effects. The monoclonal antibody enzyme fusion protein is administered before cytotoxic prodrug in this strategy. For high affinity of monoclonal antibody, monoclonal antibody enzyme fusion protein can concentrate in tumor tissues. The subsequent prodrug is activated by the enzyme part in the antibody enzyme fusion protein and thus cytotoxicity appears. Using this strategy, Vrudhula and co-workers [97] synthesized the cephalosporin prodrug of paclitaxel with self-immolative linkers which could be activated by L-49-sFv- $\beta$-Lactamase fusion protein (Figure 15). Another example of prodrug for ADEPT was designed by Bont et al. [98]. In their 
study, paclitaxel was connected to $\beta$-glucuronic acid via a carbamate linkage which could release the free drug under the presence of $\beta$-glucuronidase which demonstrated desirable anti-tumor efficacy. Also, this design is potent for ADEPT.

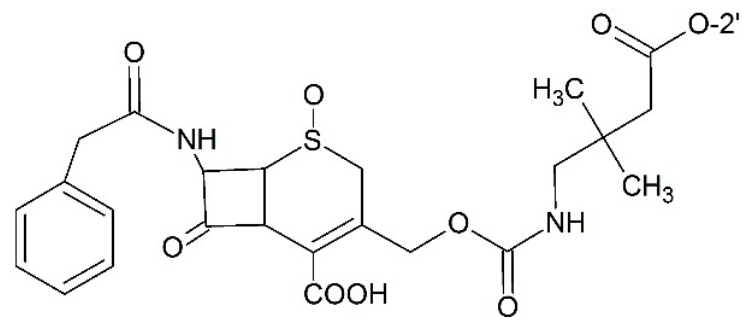

Figure 15. Prodrug for antibody directed enzyme prodrug therapy (ADEPT).

\subsubsection{Prodrugs for Gene-Directed Enzyme Prodrug Therapy (GDEPT)}

Ishida and co-workers [99] designed a paclitaxel-2'-ethylcarbonate prodrug, this prodrug converted into free paclitaxel with the help of an HSV amplicon expressing rabbit-carboxylesterase (CES) with HF10, an attenuated replication-competent virus, as a helper virus which could be used in cancer virotherapy. This approach can produce CES at the tumor sites with a high level, thus free paclitaxel can be released from the prodrug, and enhance the efficacy of HF10.

\section{Macromolecular Prodrugs}

As mentioned above, formulation of paclitaxel is of vital importance in order to avoid complicated formulations. Macromolecular paclitaxel strategies have been developed by some research groups. Macromolecular paclitaxel can not only avoid complicated formulations but also enhance the targeting ability of paclitaxel by improved permeability and retention effects (EPR). In this section, several representative macromolecules which were used to prepare the paclitaxel prodrug are discussed.

\subsection{Polyethylene Glycol (PEG)}

\subsubsection{PEG as Drug Carriers}

Initially, PEG was used as a dissolution aid for paclitaxel [100]. In order to get a more stable prodrug, a series of PEG-paclitaxel conjugates were prepared by different groups. When paclitaxel was conjugated to PEG via an amino acid spacer, the water solubility would be remarkably enhanced [101]. Greenwald et al. [102] prepared the conjugate in which the paclitaxel was attached to $\sim 40 \mathrm{kDa}$ PEG via an ester bond. The water soluble conjugate was shown to be relatively nontoxic compared to paclitaxel. However, increased toxicity was observed in the living expectancy in P388-treated mouse. Liang and co-workers [103] synthesized PEG paclitaxel conjugate via a cathepsin B cleavable linker (valine-citrulline) and a PABC spacer. The afforded conjugate showed significant advantages in terms of high water solubility, without toxic excipients, and tumor environment sensitive drug release.

\subsubsection{PEG Copolymer Prodrugs}

Although PEG is potent for paclitaxel conjugates, it is also challenged by its intrinsic property that it has only two drug loading sites at each end of the polymer. This limitation prompted the development of PEG copolymers.

Gu and co-workers [104] established a versatile platform for using prodrug micellar nanoparticles to deliver paclitaxel. Unlike other noncovalently bonding nanosystems, paclitaxel was acetal-linked to water soluble poly(ethylene glycol)-b-poly(acrylic acid) (PEG-PAA) block copolymer. The prodrug was $\mathrm{pH}$ dependent degradable and thus, paclitaxel could be released rapidly. These paclitaxel prodrug nanoparticles showed high antitumor activity to $\mathrm{KB}$ and HeLa cells $\left(\mathrm{IC}_{50}=0.18\right.$ and $0.9 \mu \mathrm{g}$ PTX 
equivalent (equiv.)/mL, respectively) as well as A549 cells, a PTX-resistant. The system showed superior anticancer activity to both drug sensitive and resistant cancer cells with remarkable efficient drug content (up to $42.8 \mathrm{wt} \%$ paclitaxel). Using this strategy, the drug loading ability of the polymer could be improved by a large amount.

Besides the drug loading ability, the co-polymer is more functional than the original PEG. Yu et al. [105] synthesized a functional polylactide-g-paclitaxel-poly(ethylene glycol) drug conjugate. In this conjugate, paclitaxel was used as a divalent agent bridging degradable azide-functionalized polylactide (PLA)-based backbone and PEG side chain. In vitro study showed the azide motif could be hydrolyzed faster at $\mathrm{pH} 5.5$ than $\mathrm{pH} 7.4$ while the ester bond is more stable at $\mathrm{pH} 5.5$ which proved the conjugate was potent to release paclitaxel faster in tumor tissues.

Lv et al. [106] synthesized the 3,3'-dithiodipropionic acid functionalized poly(ethylene glycol)- $b$-poly(L-lysine) (mPEG- $b$-P(LL-DTPA)) and paclitaxel was conjugated to this polymer. Not surprisingly, it was a redox dependent drug release conjugate. Besides, the prodrug was $\mathrm{pH}$ dependent release and exhibited high cytotoxic towards tumor cells compared to non-sensitive micelles.

Furthermore, PEG copolymer can form self-assembly micelles, which can simplify the preparation process. Chen et al. [107] prepared co-polymers with PEG side chains, and paclitaxel was covalently conjugated to the polymer via disulfide linkers. These self-assembly micelles showed apparent cytotoxicity to OS-RC-2 kidney tumor cells and low cytotoxic to normal cells (macrophage cells).

Besides mono drug therapy, paclitaxel can also combine other drugs with the aid of PEG to formulate a drug delivery system. Zhu and co-workers [108] developed a nanopreparation which was composed of matrix metalloproteinase 2 (MMP2)-sensitive self-assembly PEG2000-paclitaxel conjugate, transactivating transcriptional activator peptide-PEG1000-phosphoethanolamine (PE) which could enhance cell-penetration, and PEG1000-PE as a nanocarrier building block. This system exhibited enhanced anticancer activity, and could deliver the drug into cancer cells.

\subsubsection{PEG Linker Prodrugs}

In addition to employing PEG as a drug carrier directly or forming PEG co-polymers, PEG can also be used as a linker between carrier and paclitaxel. Bao and co-workers [109] synthesized D- $\alpha$-tocopherol polyethylene glycol succinate-based paclitaxel prodrug which was self-assembly aggregate in micelles with high drug loading. The prodrug was designed by introducing P-glycoprotein (P-gp) inhibitor and a disulfide linker to realize redox-sensitive property in tumor tissues. The prodrug was not only $91 \%$ more efficient than paclitaxel but also had increased AUC and half-life.

The paclitaxel conjugates with PEG linker could achieve targeting ability by conjugating targeting moieties. Safavy and co-workers [110,111] linked paclitaxel-PEG conjugate with BBN peptide which could bind to the cell surface bombesin/gastrin-releasing peptide receptor. The resulting prodrug retained binding affinity as the original $\mathrm{BBN}$, its $\mathrm{IC}_{50}$ was lower than free paclitaxel when tested on NCIH1299 human non-small dell lung cancer cell. In order to enhance the endocytosis of the prodrug, Yin and co-workers [112] synthesized octreotide-PEG-disulfide bond-paclitaxel conjugates. This design could realize not only targeting ability by EPR effects but also OCT-receptor mediated endocytosis. The results showed the design could be used for superior targeting redox-sensitive polymers.

\subsection{Hyaluronic Acid (HA)}

Hyaluronic acid has synergism effects with paclitaxel in inhibiting cancer migration [113]. Lee and co-workers [114] synthesized paclitaxel-hyaluronic acid conjugate via an ester bond. This conjugate could form self-assembly nanosized micellar aggregates in aqueous solution and exhibited more pronounced cytotoxicity for cancer cells overexpressing HA receptors. Yin et al. used cross linker containing disulfide bonds which is sensitive to glutathione to link paclitaxel and hyaluronic acid (HA) together. This system was also able to enhance the therapeutic efficacy of paclitaxel and provide a redox-responsive, controlled releasing, targeting platform for paclitaxel delivery [115]. 


\subsection{N-(2-Hydroxypropyl)methacrylamide (HPMA)}

$\mathrm{N}$-(2-hydroxypropyl)methacrylamide (HPMA) is also a popular macromolecule used to prepare the paclitaxel prodrug. Miller and co-workers [116] conjugated alendronate and paclitaxel to HMPA via cathepsin B cleavable peptide in which alendronate was used to target bones. The resulting conjugate exhibited improved efficacy, and could be better tolerated and administered than when formulated in Cremophor and ethanol. Erez and co-workers [117] introduced cathepsin B cleavable linker and AB3 self-immolative space to form paclitaxel HPMA conjugates. The resulting conjugate exhibited higher drug loading and enhanced cytotoxicity on murine prostate adenocarcinoma cells when compared to a classic monomeric drug-polymer conjugate. In addition to peptide linker, other linker strategies were also developed. Etrych et al. [118] synthesized HMPA copolymer-paclitaxel conjugates by inducing hydrolytic cleavable linkage which was formed by the reaction of the hydrazide group-terminated side chain of the polymer with the carbonyl group of a drug derivative. In vitro study showed this conjugate could release paclitaxel faster at $\mathrm{pH} 5$ compared to $\mathrm{pH}$ 7. Furthermore, this conjugate showed better anti-tumor activity in the $4 \mathrm{~T} 1$ model of mammary carcinoma than the parent paclitaxel.

\subsection{Dendrimers}

Dendrimer is a kind of highly branched polymer. Although dendrimers are less popular than other polymers in delivering paclitaxel, a dendrimer delivery system has some advantages over other polymer delivery systems. It can form a monodispersed drug delivery system. Reproducible pharmacokinetics and pharmacodynamics could be observed from batch to batch. Some specific dendrimer paclitaxel carrier could also influence tubulin stability including polyamidoamine (PAMAM) [119].

PEGylated triazine dendrimers containing 12 paclitaxel binding sites were synthesized with different ester or disulfide linkers between the core and the $2^{\prime}-\mathrm{OH}$ in paclitaxel [120]. This group also carried out in vivo experiments of these polymers. Just as they hypothesized, introducing a labile disulfide linker formed a more cytotoxic prodrug [121]. After this, PEGylated triazine dendrimers for paclitaxel delivery received further development [122]. Dendrimers of this kind with approximately 16 paclitaxel binding sites and eight PEG group (Figure 16) binding sites were built up in different ways. The best construction is shown in Figure 16 [123]. Apart from this, highly branched dendrimer can also protect siRNA from RNase digestion which makes dendrimer an ideal carrier for combining paclitaxel to siRNA. Kala and coworkers [124] reported that co-delivering paclitaxel and Akt siRNA by a triethanolamine-core poly(amidoamine) dendrimer showed great potential for treating ovarian cancer.

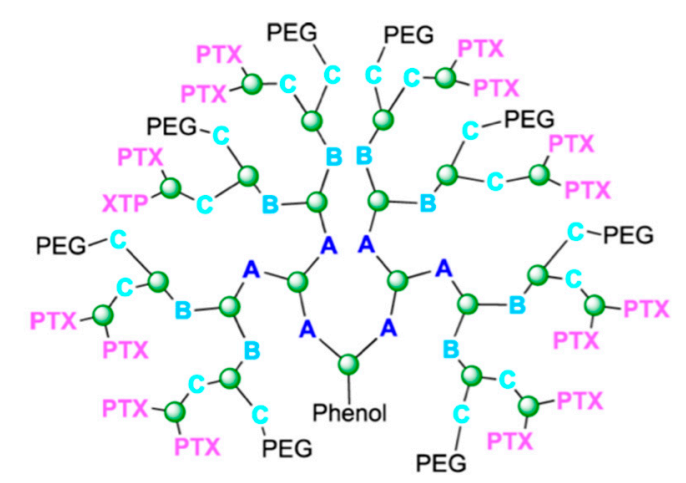

Figure 16. Dendrimer with 16 paclitaxel binding site and 8 PEG binding sites. Reproduced with permission from Reference [123]. Green atoms are 1,3,5-Trichlorotriazine, PEG is polyethylene glycol, PTX is Paclitaxel, A is 1,3-Bis(4-piperidyl)propane, B is Piperazine, C is 4-Piperidinemethanamine.

Satsangi and co-workers [125] synthesized paclitaxel poly(amidoamine) dendrimer conjugates with capthesin B cleavable peptide linker (Gly-Phe-Leu-Gly). This design enabled the conjugates to 
release paclitaxel in tumor tissues where capthesin B activity is relatively high compared to normal tissues. In this way the conjugates achieved markedly higher tumor reduction compared to paclitaxel in the MDA-MB-231 model.

For PEG drug conjugates, their intrinsic limitation is owing to PEG's chemical structure where only the end can form conjugates. In order to get a higher amount of payload, Clementi et al. [126] developed a strategy giving PEG a dendrimer at each end. By using this method, paclitaxel and alendronate were conjugated to the $\mathrm{H}_{2} \mathrm{~N}-\mathrm{PEG}$-dendrimer- $(\mathrm{COOH})_{4}$, this conjugate exhibited an increased half-life, and could be resolved in the physical environment without Cremophor EL.

\subsection{Other Polymers}

In order to avoid complicated formulation, paclitaxel was conjugated to low molecular weight chitosan with a cleavable ester bond. As a result, water solubility was enhanced to $>1 \mathrm{mg} / \mathrm{mL}$ with comparable $\mathrm{IC}_{50}$, and the prodrug could be administered orally [127].

There is another property of paclitaxel which has directed the development of macromolecular paclitaxel prodrugs. It had been shown that paclitaxel's efficacy is more dependent on exposure time rather than on its concentration [128]. Therefore, a slow release system is more efficient in delivering paclitaxel. Cavallaro et al. [129] first used $\alpha, \beta$-Poly(N-2-hydroxyethyl)-DL-aspartamide (PHEA) whose properties were similar to plasma as paclitaxel succinic anhydride derivative carriers linked by an ester bond whichcould be cleaved by an enzyme. This system showed high drug loading, stable in plasma, and prolonged drug release. By using polylactide, Yu and co-workers [130] designed brush polymer for azide-functionalized paclitaxel sustained delivering.

Delela [131] synthesized the conjugate in which paclitaxel was attached to poly (styrene-co-maleic acid), this self-assembly formed nanoparticles exhibiting $\mathrm{pH}$ dependent release, increasing in $C_{\max }$ and half-life, and could be detained in the tumor via an enhanced permeability and retention effect (EPR).

Wang and co-workers [132] synthesized heparin-paclitaxel conjugates via a single amino acid linker, in which heparin could inhibit tumor development. Results showed the anticoagulant activity of the prodrug was decreased sharply compared to heparin. This meant the prodrug strategy was safe to be administered systemically. This prodrug did not only have a self-assembly property in preparation, but also exhibited better cell inhibition for MCF-7 cells than free paclitaxel. The targeting capacity to solid tumor was also enhanced in this design.

\subsection{Proteins}

Aiming to avoid using Cremophor EL, choosing proper drug formulation or carrier is vitally important. Dosio and co-workers [133] conjugated paclitaxel to human serum albumin. The afforded conjugate became biocompatible and could be internalized into cells followed by drug release inside the cell. This conjugate could also release parent drug continuously to provide a depot effect.

Conjugating to antibody is an efficient approach for getting better target ability. Using this method, drugs can be specifically delivered to tumor sites and fewer side effects could be observed. Safavy and co-workers [134] conjugated paclitaxel to anti-epidermal growth factor receptor (anti-EGFR) momoclonal antibody Erbitux (C225) via a succinic acid linker. With regard to the conjugate, the $24 \mathrm{~h}$ tumor uptake was not significantly different from the original Mab, which meant paclitaxel bonding did not affect the antigen-binding and original inhibiting properties of C225, an early cleavage of the drug was observed. After this, glutaric acid linker was employed for avoiding early cleavage in circulation. This linker based antibody drug conjugate (ADC) exhibited better antitumor activity.

\section{Nanodevices}

As mentioned above, there have been many varieties of polymers, dendrimers, and proteins used to conjugate with paclitaxel as carriers. Besides these carriers, nanodevices have also been employed in developing paclitaxel prodrugs. Yuan and co-workers [135] developed an approach to bond paclitaxel to fluorescent mesoporous silica nanoparticles (FMSN) covalently via disulfide linker which was 
sensitive to glutathione concentration. This conjugate could load up to $13 \%$ by weight. In vitro study showed this conjugate could be effectively taken up by Hela cells with reduced toxicity and side effects. Fluorescent silicon oxide based paclitaxel conjugate also showed great potential for clinical use [136].

In order to get better water solubility, Ding and co-workers [137] added PEG spacer to gold nanoparticles to form thiol terminated PEG-paclitaxel-conjugates. Water solubility was enhanced by $4.6 \times 10^{5}$ times compared to free paclitaxel. The conjugate also exhibited improved cytotoxicity and prolonged circulation. Gibson and co-workers [138] first synthesized $2 \mathrm{~nm}$ gold nanoparticles conjugated with paclitaxel. In the study, paclitaxel was attached to a hexaethylene glycol linker at the 7-OH and then the linker was linked to phenol-terminated gold nanocrystals. This offered an opportunity to develop gold based conjugates.

$\mathrm{Xu}$ and co-workers [139] used PEGylated graphene oxide as drug carrier, paclitaxel was linked to PEG via a succinic liner. The resulting conjugate showed high water solubility and bioavailability, and could be quickly absorbed by lung cancer cell A549 and breast cancer MCF7. Besides graphene, fullerene could also be employed as drug carrier. Zakharian and co-workers [140] developed a fullerene-paclitaxel conjugate to realize slow-release property and also made a single dose "drug cocktail" for paclitaxel possible.

\section{Conclusions}

Paclitaxel is a promising antitumor agent which was originally separated from natural plants. However, there are some limitations towards its wide clinical application. Hence, efforts to obtain smarter targeting paclitaxel have never stopped. In the early stage of paclitaxel's development strategies, studies mainly focused on the problem of low water solubility. As more and more research groups contributed to paclitaxel's preparation, diverse prodrug techniques were used to obtain more efficient paclitaxel. With modern preparation methods, the anti-tumor activity of paclitaxel can be enhanced a great deal. However, for improved formulation or drug combination, there still remains a lot of work to be carried out by scientists in the future. Furthermore, recently many groups have published their works on self-assembly nano particles which can be prepared easily. This may be the trend to replace traditional complicated preparation manners and formulation. Besides drug formulation, enhancing the targeting ability of paclitaxel with fewer side effects is also a challenge. In the traditional way, paclitaxel prodrugs can achieve targeting ability by employing targeting moieties including tumor cell over-expressed proteins recognizing peptide or small molecules, and employing linkers which are sensitive to the tumor environment. Whether there is a better way for paclitaxel to obtain targeting activity is still under development.

Acknowledgments: We thank the other academic staff members in Aiping Lu and Ge Zhang's group at Hong Kong Baptist University Hong Kong, China. We also thank Hong Kong Baptist University for providing critical comments and technical support. This study was supported by the Hong Kong General Research Fund (HKBU12102914 to Ge Zhang) and the Faculty Research Grant of Hong Kong Baptist University (FRG2/12-13/027 to Ge Zhang).

Author Contributions: Ziyuan Meng and Quanxia Lv wrote the manuscript. Houzong Yao, Jun Lu, and Xiaoqing Lv contributed the manuscript for literature research. Feng Jiang, Aiping Lu and Ge Zhang revised and approved the manuscript.

Conflicts of Interest: The authors declare no conflict of interest.

\section{References}

1. Wani, M.C.; Taylor, H.L.; Wall, M.E.; Coggon, P.; McPhail, A.T. Plant antitumor agents. VI. Isolation and structure of taxol, a novel antileukemic and antitumor agent from Taxus brevifolia. J. Am. Chem. Soc. 1971, 93, 2325-2327. [CrossRef] [PubMed]

2. De Furia, M.D. Paclitaxel (Taxol ${ }^{\circledR}$ ): A new natural product with major anticancer activity. Phytomedicine 1997, 4, 273-282. [CrossRef] 
3. MacCari, G.; Mori, M.; Rodríguez-Salarichs, J.; Fang, W.; Díaz, J.F.; Botta, M. Free energy profile and kinetics studies of paclitaxel internalization from the outer to the inner wall of microtubules. J. Chem. Theory Comput. 2013, 9, 698-706. [CrossRef] [PubMed]

4. Grover, S.; Rimoldis, J.M.; Molinero, A.A.; Chaudhary, A.G.; Kingston, D.G.; Hamel, E. Different effects of paclitaxel (Taxel) analogs modified at position C-2, C-7, and C-3' on tubulin polymerization and polymer stabilization: Identification of a hyperactive paclitaxel derivative. Biochemistry 1995, 34, 3927-3934. [CrossRef] [PubMed]

5. Li, Y.; Edsall, R.; Jagtap, P.G.; Kingston, D.G.I.; Bane, S. Equilibrium studies of a fluorescent paclitaxel derivative binding to microtubules. Biochemistry 2000, 39, 616-623. [CrossRef] [PubMed]

6. Javeed, A.; Ashraf, M.; Riaz, A.; Ghafoor, A.; Afzal, S.; Mahmood, M. Paclitaxel and immune system. Eur. J. Pharm. Sci. 2009, 38, 283-290. [CrossRef] [PubMed]

7. Brunden, K.R.; Trojanowski, J.Q.; Smith, A.B.; Lee, V.M.Y.; Ballatore, C. Microtubule-stabilizing agents as potential therapeutics for neurodegenerative disease. Bioorg. Med. Chem. 2014, 22, 5040-5049. [CrossRef] [PubMed]

8. Dadgar, S.; Ramjan, Z.; Floriano, W.B. Paclitaxel is an inhibitor and its boron dipyrromethene derivative is a fluorescent recognition agent for botulinum neurotoxin subtype A. J. Med. Chem. 2013, 56, 2791-2803. [CrossRef] [PubMed]

9. Ooya, T.; Lee, J.; Park, K. Hydrotropic dendrimers of generations 4 and 5: Synthesis, characterization, and hydrotropic solubilization of paclitaxel. Bioconjug. Chem. 2004, 15, 1221-1229. [CrossRef] [PubMed]

10. Menger, F.M.; Zhang, H.; de Joannis, J.; Kindt, J.T. Solubilization of Paclitaxel (taxol) by peptoad self-assemblies. Langmuir 2007, 23, 2308-2310. [CrossRef] [PubMed]

11. Inada, A.; Oshima, T.; Baba, Y. Enhancing the water dispersibility of paclitaxel by complexation with hydrophobic peptides. Colloids Surf. B Biointerfaces 2015, 135, 408-415. [CrossRef] [PubMed]

12. Nanda, R.; Sasmal, A.; Nayak, P.L. Preparation and characterization of chitosan-polylactide composites blended with Cloisite 30B for control release of the anticancer drug paclitaxel. Carbohydr. Polym. 2011, 83, 988-994. [CrossRef]

13. Aleandri, S.; Bandera, D.; Mezzenga, R.; Landau, E.M. Biotinylated cubosomes: A versatile tool for active targeting and co-delivery of paclitaxel and fluorescein-based lipid dye. Langmuir 2015, 108, 12770-12776. [CrossRef] [PubMed]

14. Liu, Y.; Chen, G.-S.; Chen, Y.; Cao, D.-X.; Ge, Z.-Q.; Yuan, Y.-J. Inclusion complexes of paclitaxel and oligo(ethylenediamino) bridged bis( $\beta$-cyclodextrin)s: Solubilization and antitumor activity. Bioorg. Med. Chem. 2004, 12, 5767-5775. [CrossRef] [PubMed]

15. Boztas, A.O.; Karakuzu, O.; Galante, G.; Ugur, Z.; Kocabas, F.; Altuntas, C.Z.; Yazaydin, A.O. Synergistic interaction of paclitaxel and curcumin with cyclodextrin polymer complexation in human cancer cells. Mol. Pharm. 2013, 10, 2676-2683. [CrossRef] [PubMed]

16. Singh, A.V.; Batuwangala, M.; Mundra, R.; Mehta, K.; Patke, S.; Falletta, E.; Patil, R.; Gade, W.N. Biomineralized anisotropic gold microplate-macrophage interactions reveal frustrated phagocytosis-like phenomenon: A novel paclitaxel drug delivery vehicle. ACS Appl. Mater. Interfaces 2014, 6, 14679-14689. [CrossRef] [PubMed]

17. Ren, F.; Bhana, S.; Norman, D.D.; Johnson, J.; Xu, L.; Baker, D.L.; Parrill, A.L.; Huang, X. Gold nanorods carrying paclitaxel for photothermal-chemotherapy of cancer. Bioconjug. Chem. 2013, 24, 376-386. [CrossRef] [PubMed]

18. Joshi, N.; Saha, R.; Shanmugam, T.; Balakrishnan, B.; More, P.; Banerjee, R. Carboxymethyl-chitosan-tethered lipid vesicles: Hybrid nanoblanket for oral delivery of paclitaxel. Biomacromolecules 2013, 14, 2272-2282. [CrossRef] [PubMed]

19. Kang, Y.; Wu, J.; Yin, G.; Huang, Z.; Liao, X.; Yao, Y.; Ouyang, P.; Wang, H.; Yang, Q. Characterization and biological evaluation of paclitaxel-loaded poly(L-lactic acid) microparticles prepared by supercritical $\mathrm{CO}_{2}$. Langmuir 2008, 24, 7432-7441. [CrossRef] [PubMed]

20. Sahoo, S.K.; Labhasetwar, V. Enhanced antiproliferative activity of nanoparticles, transferrin-conjugated paclitaxel-loaded. Mol. Pharm. 2005, 2, 373-383. [CrossRef] [PubMed]

21. Zhang, F.; Zhang, S.; Pollack, S.F.; Li, R.; Gonzalez, A.M.; Fan, J.; Zou, J.; Leininger, S.E.; Pavía-Sanders, A.; Johnson, R.; et al. Improving Paclitaxel Delivery: In Vitro and In Vivo characterization of PEGylated polyphosphoester-based nanocarriers. J. Am. Chem. Soc. 2015, 137, 2056-2066. [CrossRef] [PubMed] 
22. Shi, Y.; van Nostrum, C.F.; Hennink, W.E. Interfacially Hydrazone cross-linked thermosensitive polymeric micelles for acid-triggered release of paclitaxel. ACS Biomater. Sci. Eng. 2015, 1, 393-404. [CrossRef]

23. Zhang, X.; Huang, Y.; Zhao, W.; Chen, Y.; Zhang, P.; Li, J.; Venkataramanan, R.; Li, S. PEG-farnesyl thiosalicylic acid telodendrimer micelles as an improved formulation for targeted delivery of paclitaxel. Mol. Pharm. 2014, 11, 2807-2814. [CrossRef] [PubMed]

24. Zhang, X.; Lu, J.; Huang, Y.; Zhao, W.; Chen, Y.; Li, J.; Gao, X.; Venkataramanan, R.; Sun, M.; Stolz, D.B.; et al. PEG-farnesylthiosalicylate conjugate as a nanomicellar carrier for delivery of paclitaxel. Bioconjug. Chem. 2013, 24, 464-472. [CrossRef] [PubMed]

25. Zhang, X.; Liu, K.; Huang, Y.; Xu, J.; Li, J.; Ma, X.; Li, S. Reduction-sensitive dual functional nanomicelles for improved delivery of Paclitaxel. Bioconjug. Chem. 2014, 25, 1689-1696. [CrossRef] [PubMed]

26. Guo, Y.; Wang, X.; Shu, X.; Shen, Z.; Sun, R.C. Self-assembly and paclitaxel loading capacity of cellulose-grazft-poly(lactide) nanomicelles. J. Agric. Food Chem. 2012, 60, 3900-3908. [CrossRef] [PubMed]

27. Liu, Y.; Mei, L.; Yu, Q.; Xu, C.; Qiu, Y.; Yang, Y.; Shi, K.; Zhang, Q.; Gao, H.; Zhang, Z.; et al. Multifunctional Tandem peptide modified paclitaxel-loaded liposomes for the treatment of vasculogenic mimicry and cancer stem cells in malignant glioma. ACS Appl. Mater. Interfaces 2015, 7, 16792-16801. [CrossRef] [PubMed]

28. Liu, Y.; Huang, L.; Liu, F. Paclitaxel nanocrystals for overcoming multidrug resistance in cancer. Mol. Pharm. 2010, 7, 863-869. [CrossRef] [PubMed]

29. Field, J.J.; Kanakkanthara, A.; Miller, J.H. Microtubule-targeting agents are clinically successful due to both mitotic and interphase impairment of microtubule function. Bioorg. Med. Chem. 2014, 22, 5050-5059. [CrossRef] [PubMed]

30. Jiang, S.; Pan, A.W.; Lin, T.; Zhang, H.; Malfatti, M.; Turteltaub, K.; Henderson, P.T.; Pan, C. Paclitaxel enhances carboplatin-DNA adduct formation and cytotoxicity. Chem. Res. Toxicol. 2015, 28, 2250-2252. [CrossRef] [PubMed]

31. Andreoli, M.; Persico, M.; Kumar, A.; Orteca, N.; Kumar, V.; Pepe, A.; Mahalingam, S.; Alegria, A.E.; Petrella, L.; Sevciunaite, L.; et al. Identification of the first inhibitor of the GBP1:PIM1 interaction. Implications for the development of a new class of anticancer agents against paclitaxel resistant cancer cells. J. Med. Chem. 2014, 57, 7916-7932. [CrossRef] [PubMed]

32. Dai, X.; Fan, W.; Wang, Y.; Huang, L.; Jiang, Y.; Shi, L.; Mckinley, D.; Tan, W.; Tan, C. Combined delivery of Let-7b microRNA and Paclitaxel via biodegradable nanoassemblies for the treatment of KRAS mutant cancer. Mol. Pharm. 2016, 13, 520-533. [CrossRef] [PubMed]

33. Shen, J.; Meng, Q.; Sui, H.; Yin, Q.; Zhang, Z.; Yu, H.; Li, Y. IRGD conjugated TPGS mediates codelivery of paclitaxel and survivin shRNA for the reversal of lung cancer resistance. Mol. Pharm. 2014, 11, 2579-2591. [CrossRef] [PubMed]

34. Sun, T.-M.; Du, J.-Z.; Yao, Y.-D.; Mao, C.-Q.; Dou, S.; Huang, S.-Y.; Zhang, P.-Z.; Leong, K.W.; Song, E.-W.; Wang, J. Simultaneous delivery of siRNA and paclitaxel via a "Two-in-One" micelleplex promotes synergistic tumor suppression. ACS Nano 2011, 5, 1483-1494. [CrossRef] [PubMed]

35. Damen, E.W.P.; Nevalainen, T.J.; van den Bergh, T.J.M.; de Groot, F.M.H.; Scheeren, H.W. Synthesis of novel paclitaxel prodrugs designed for bioreductive activation in hypoxic tumour tissue. Bioorg. Med. Chem. 2002, 10, 71-77. [CrossRef]

36. Smith, A.B., III; Sugasawa, K.; Atasoylu, O.; Yang, C.P.H.; Horwitz, S.B. Design and synthesis of (+)-discodermolide-paclitaxel hybrids leading to enhanced biological activity. J. Med. Chem. 2011, 54, 6319-6327. [CrossRef] [PubMed]

37. Wittman, M.D.; Altstadt, T.J.; Fairchild, C.; Hansel, S.; Johnston, K.; Kadow, J.F.; Long, B.H.; Rose, W.C.; Vyas, D.M.; Wu, M.J.; et al. Synthesis of metabolically blocked paclitaxel analogues. Bioorg. Med. Chem. Lett. 2001, 11, 809-810. [CrossRef]

38. Ganesh, T.; Yang, C.; Norris, A.; Glass, T.; Bane, S.; Ravindra, R.; Banerjee, A.; Metaferia, B.; Thomas, S.L.; Giannakakou, P.; et al. Evaluation of the tubulin-bound paclitaxel conformation: Synthesis, biology, and SAR studies of C-4 to C-3' bridged paclitaxel analogues. J. Med. Chem. 2007, 50, 713-725. [CrossRef] [PubMed]

39. Tang, S.; Yang, C.; Brodie, P.; Bane, S.; Ravindra, R.; Sharma, S.; Jiang, Y.; Snyder, J.P.; Kingston, D.G. Bridging converts a noncytotoxic nor-paclitaxel derivative to a cytotoxic analogue by constraining it to the T-Taxol conformation. Org. Lett. 2006, 8, 3983-3986. [CrossRef] [PubMed] 
40. Shanker, N.; Kingston, D.G.I.; Ganesh, T.; Yang, C.; Alcaraz, A.A.; Geballe, M.T.; Banerjee, A.; McGee, D.; Snyder, J.P.; Bane, S. Enhanced microtubule binding and tubulin assembly properties of conformationally constrained paclitaxel derivatives. Biochemistry 2007, 46, 11514-11527. [CrossRef] [PubMed]

41. Choy, N.; Shin, Y.; Nguyen, P.Q.; Curran, D.P.; Balachandran, R.; Madiraju, C.; Day, B.W. Simplified Discodermolide Analogues: Synthesis and Biological Evaluation of 4-epi-7-Dehydroxy-14,16-didemethyl(+)-discodermolides as Microtubule-Stabilizing Agents. J. Med. Chem. 2003, 46, 2846-2864. [CrossRef] [PubMed]

42. Podduturi, V.P.; Magaña, I.B.; O'Neal, D.P.; Derosa, P.A. Simulation of transport and extravasation of nanoparticles in tumors which exhibit enhanced permeability and retention effect. Comput. Methods Progr. Biomed. 2013, 112, 58-68. [CrossRef] [PubMed]

43. Ballone, P.; Marchi, M. A density functional study of a new family of anticancer drugs: Paclitaxel, taxotere, epothilone, and discodermolide. J. Phys. Chem. A 1999, 103, 3097-3102. [CrossRef]

44. Chaudhary, A.G.; Chordia, M.D.; Kingston, D.G.I. A novel benzoyl group migration: Synthesis and biological evaluation of 1-Benzoyl-2-des (benzoy1oxy)paclitaxe. J. Org. Chem. 1996, 60, 3260-3262. [CrossRef]

45. Zhu, Q.; Huang, N.; Wang, M.; Chu, F. Comparative molecular field analysis of a series of paclitaxel analogs. J. Med. Chem. 1997, 40, 4319-4328. [CrossRef] [PubMed]

46. Moyna, G.; Williams, H.J.; Scott, A.I.; Ringel, I.; Gorodetsky, R.; Swindell, C.S. Conformational studies of paclitaxel analogs modified at the C-2' position in hydrophobic and hydrophilic solvent systems. J. Med. Chem. 1997, 40, 3305-3311. [CrossRef] [PubMed]

47. Sharma, S.; Lagisetti, C.; Poliks, B.; Coates, R.M.; Kingston, D.G.I.; Bane, S. Dissecting paclitaxel-Microtubule association: Quantitative assessment of the 2'-OH group. Biochemistry 2013, 52, 2328-2336. [CrossRef] [PubMed]

48. Milanesio, M.; Ugliengo, P.; Viterbo, D.; Appendino, G. Ab initio conformational study of the phenylisoserine side chain of paclitaxel. J. Med. Chem. 1999, 42, 291-299. [CrossRef] [PubMed]

49. Altstadt, T.J.; Fairchild, C.R.; Golik, J.; Johnston, K.A.; Kadow, J.F.; Lee, F.Y.; Long, B.H.; Rose, W.C.; Vyas, D.M.; Wong, H.; et al. Synthesis and antitumor activity of novel C-7 paclitaxel ethers: Discovery of BMS-184476. J. Med. Chem. 2001, 44, 4577-4583. [CrossRef] [PubMed]

50. Khmelnitsky, Y.L.; Budde, C.; Arnold, J.M.; Usyatinsky, A.; Clark, D.S.; Dordick, J.S. Synthesis of water-soluble paclitaxel derivatives by enzymatic acylation. J. Am. Chem. Soc. 1997, 119, 11554-11555. [CrossRef]

51. Wrasidlo, W.; Gaedicke, G.; Guy, R.K.; Renaud, J.; Pitsinos, E.; Nicolaou, K.C.; Reisfeld, R.A.; Lode, H.N. A novel 2'-(N-methylpyridinium acetate) prodrug of paclitaxel induces superior antitumor responses in preclinical cancer models. Bioconjug. Chem. 2002, 13, 1093-9109. [CrossRef] [PubMed]

52. Ali, S.M.; Hoemann, M.Z.; Aub, J.; Mitscher, L.A.; Georg, G.I. Novel cytotoxic 3'-(tert-Butyl) 3'-dephenyl analogs of paclitaxel and docetaxel. J. Med. Chem. 1996, 38, 3821-3828. [CrossRef]

53. Kingston, D.G.; Chaudhary, A.G.; Chordia, M.D.; Gharpure, M.; Gunatilaka, A.L.; Higgs, P.I.; Rimoldi, J.M.; Samala, L.; Jagtap, P.G.; Giannakakou, P.; et al. Synthesis and biological evaluation of 2-acyl analogues of paclitaxel (Taxol). J. Med. Chem. 1998, 41, 3715-3726. [CrossRef] [PubMed]

54. Chen, S.; Kadow, J.F.; Farinat, V.; Fairchild, C.R.; Johnston, K.A.; Med, I. First Syntheses of novel paclitaxel(taxol) analogs modified at C4-position. J. Org. Chem. 1994, 59, 6156-6158. [CrossRef]

55. Barboni, L.; Giarlo, G.; Ricciutelli, M.; Ballini, R.; Georg, G.I.; VanderVelde, D.G.; Himes, R.H.; Wang, M.; Lakdawala, A.; Snyder, J.P.; et al. Synthesis, modeling, and anti-tubulin activity of a D-Seco paclitaxel analogue. Org. Lett. 2004, 6, 461-464. [CrossRef] [PubMed]

56. Chen, S.; Fairchild, C.; Lon, B.H. Synthesis and biological evaluation of novel C-4 aziridine-bearing paclitaxel (Taxol) analogs. J. Med. Chem. 1995, 38, 2263-2267. [CrossRef] [PubMed]

57. Walker, M.A.; Johnson, T.D.; Huang, S.; Vyas, D.M.; Kadow, J.F. Synthesis of a novel C-10 spiro-epoxide of paclitaxel. Bioorg. Med. Chem. Lett. 2001, 11, 1683-1685. [CrossRef]

58. Chen, S.-H.; Farina, V.; Vyas, D.M.; Doyle, T.W.; Long, B.H.; Fairchild, C. Synthesis and biological evaluation of C-13 amide-linked paclitaxel (Taxol) analogs. J. Org. Chem. 1996, 61, 2065-2070. [CrossRef]

59. Gunatilaka, A.A.L.; Ramdayal, F.D.; Sarragiotto, M.H.; Kingston, D.G.I.; Sackett, D.L.; Hamel, E. Synthesis and biological evaluation of novel paclitaxel (Taxol) D-ring modified analogues. J. Org. Chem. 1999, 64, 2694-2703. [CrossRef] [PubMed] 
60. Metaferia, B.B.; Hoch, J.; Glass, T.E.; Bane, S.L.; Chatterjee, S.K.; Snyder, J.P.; Lakdawala, A.; Cornett, B.; Kingston, D.G.I. Synthesis and biological evaluation of novel macrocyclic paclitaxel analogues. Org. Lett. 2001, 3, 2461-2464. [CrossRef] [PubMed]

61. Hayashi, Y.; Skwarczynski, M.; Hamada, Y.; Sohma, Y.; Kimura, T.; Kiso, Y. A novel approach of water-soluble paclitaxel prodrug with no auxiliary and no byproduct: Design and synthesis of isotaxel. J. Med. Chem. 2003, 46, 3782-3784. [CrossRef] [PubMed]

62. Golik, J.; Wong, H.S.L.; Chen, S.H.; Doyle, T.W.; Wright, J.J.K.; Knipe, J.; Rose, W.C.; Casazza, A.M.; Vyas, D.M. Synthesis and antitumor evaluation of paclitaxel phosphonooxymethyl ethers: A Novel class of water soluble paclitaxel pro-drugs. Bioorg. Med. Chem. Lett. 1996, 6, 1837-1842. [CrossRef]

63. Ueda, Y.; Matiskella, J.D.; Mikkilinenit, A.B.; Farinal, V.; Knipe, J.O.; Roset, W.C.; Casazzat, A.M.; Vyas, D.M. Novel, water-soluble phosphate derivatives of 2'-ethoxy carbonylpaclitaxel as potential prodrugs of paclitaxel: Synthesis and antitumor evaluation. Bioorg. Med. Chem. Lett. 1995, 5, 247-252. [CrossRef]

64. Damen, E.W.P.; Wiegerinck, P.H.G.; Braamer, L.; Sperling, D.; de Vos, D.; Scheeren, H.W. Paclitaxel esters of malic acid as prodrugs with improved water solubility. Bioorg. Med. Chem. 2000, 8, 427-432. [CrossRef]

65. Niethammer, A.; Gaedicke, G.; Lode, H.N.; Wrasidlo, W. Synthesis and preclinical characterization of a paclitaxel prodrug with improved antitumor activity and water solubility. Bioconjug. Chem. 2001, 12, 414-420. [CrossRef] [PubMed]

66. Ansell, S.M.; Johnstone, S.A.; Tardi, P.G.; Lo, L.; Xie, S.; Shu, Y.; Harasym, T.O.; Harasym, N.L.; Williams, L.; Bermudes, D.; et al. Modulating the therapeutic activity of nanoparticle delivered paclitaxel by manipulating the hydrophobicity of prodrug conjugates. J. Med. Chem. 2008, 51, 3288-3296. [CrossRef] [PubMed]

67. Wohl, A.R.; Michel, A.R.; Kalscheuer, S.; Macosko, C.W.; Panyam, J.; Hoye, T.R. Silicate esters of paclitaxel and docetaxel: Synthesis, hydrophobicity, hydrolytic stability, cytotoxicity, and prodrug potential. J. Med. Chem. 2014, 57, 2368-2379. [CrossRef] [PubMed]

68. Han, J.; Michel, A.R.; Lee, H.S.; Kalscheuer, S.; Wohl, A.; Hoye, T.R.; McCormick, A.V.; Panyam, J.; Macosko, C.W. Nanoparticles containing high loads of paclitaxel-silicate prodrugs: Formulation, drug release, and anticancer efficacy. Mol. Pharm. 2015, 12, 4329-4335. [CrossRef] [PubMed]

69. Dosio, F.; Reddy, L.H.; Ferrero, A.; Stella, B.; Cattel, L.; Couvreur, P. Novel nanoassemblies composed of squalenoyl-paclitaxel derivatives: Synthesis, characterization, and biological evaluation. Bioconjug. Chem. 2010, 21, 1349-1361. [CrossRef] [PubMed]

70. Wittman, M.D.; Kadow, J.F.; Vyas, D.M.; Lee, F.L.; Rose, W.C.; Long, B.H.; Fairchild, C.; Johnston, K. Synthesis and antitumor activity of novel paclitaxel-chlorambucil hybrids. Bioorg. Med. Chem. Lett. 2001, 11, 811-814. [CrossRef]

71. Li, X.; Yu, J.; Xu, S.; Wang, N.; Yang, H.; Yan, Z.; Cheng, G.; Liu, G. Chemical conjugation of muramyl dipeptide and paclitaxel to explore the combination of immunotherapy and chemotherapy for cancer. Glycoconj. J. 2008, 25, 415-425. [CrossRef] [PubMed]

72. Ma, Y.; Zhao, N.; Liu, G. Conjugate (MTC-220) of muramyl dipeptide analogue and paclitaxel prevents both tumor growth and metastasis in mice. J. Med. Chem. 2011, 54, 2767-2777. [CrossRef] [PubMed]

73. Caron, J.; Maksimenko, A.; Mougin, J.; Couvreur, P.; Dasmaele, D. Combined antitumoral therapy with nanoassemblies of bolaform polyisoprenoyl paclitaxel/gemcitabine prodrugs. Polym. Chem. 2014, 5, 1662. [CrossRef]

74. Vrudhula, V.M.; MacMaster, J.F.; Li, Z.; Kerr, D.E.; Senter, P.D. Reductively activated disulfide prodrugs of paclitaxel. Bioorg. Med. Chem. Lett. 2002, 12, 3591-3594. [CrossRef]

75. Trant, J.F.; McEachran, M.J.; Sran, I.; Turowec, B.A.; de Bruyn, J.R.; Gillies, E.R. Covalent polyisobutylene-paclitaxel conjugates for controlled release from potential vascular stent coatings. ACS Appl. Mater. Interfaces 2015, 7, 14506-14517. [CrossRef] [PubMed]

76. Lin, C.-E.; Garvey, D.S.; Janero, D.R.; Letts, L.G.; Marek, P.; Richardson, S.K.; Serebryanik, D.; Shumway, M.J.; Tam, S.W.; Trocha, A.M.; et al. V Combination of paclitaxel and nitric oxide as a novel treatment for the reduction of restenosis. J. Med. Chem. 2004, 47, 2276-2282. [CrossRef] [PubMed]

77. Dubowchik, G.M.; Mosure, K.; Knipe, J.O.; Firestone, R.A. Cathepsin B-sensitive dipeptide prodrugs. 2. Models of anticancer drugs paclitaxel (Taxol), mitomycin C and doxorubicin. Bioorg. Med. Chem. Lett. 1998, 8, 3347-3352. [CrossRef] 
78. Ojima, I.; Duclos, O.; Dorman, G.; Simonot, B.; Prestwich, G.D.; Rao, S.; Lerro, K.A.; Horwitz, S.B. A New paclitaxel photoaffinity analog with a 3-(4-Benzoylphenyl)propanyl probe for characterization of drug-binding sites on tubulin and P-glycoprotein. J. Med. Chem. 1995, 38, 3891-3894. [CrossRef] [PubMed]

79. Rice, A.; Liu, Y.; Michaelis, M.L.; Himes, R.H.; Georg, G.I.; Audus, K.L. Chemical modification of paclitaxel (Taxol) reduces P-glycoprotein interactions and increases permeation across the blood-brain barrier in vitro and in situ. J. Med. Chem. 2005, 48, 832-838. [CrossRef] [PubMed]

80. Skwarczynski, M.; Noguchi, M.; Hirota, S.; Sohma, Y.; Kimura, T.; Hayashi, Y.; Kiso, Y. Development of first photoresponsive prodrug of paclitaxel. Bioorg. Med. Chem. Lett. 2006, 16, 4492-4496. [CrossRef] [PubMed]

81. Noguchi, M.; Skwarczynski, M.; Prakash, H.; Hirota, S.; Kimura, T.; Hayashi, Y.; Kiso, Y. Development of novel water-soluble photocleavable protective group and its application for design of photoresponsive paclitaxel prodrugs. Bioorg. Med. Chem. 2008, 16, 5389-5397. [CrossRef] [PubMed]

82. Bradleya, M.O.; Swindella, C.S.; Anthonya, F.H.; Witmana, P.A.; Devanesana, P.; Webb, N.L.; Baker, S.D.; Wolff, A.C.; Donehower, R.C. Tumor targeting by conjugation of DHA to paclitaxel. J. Control. Release 2001, 74, 233-236. [CrossRef]

83. El Alaoui, A.; Saha, N.; Schmidt, F.; Monneret, C.; Florent, J.C. New Taxol ${ }^{\circledR}$ (paclitaxel) prodrugs designed for ADEPT and PMT strategies in cancer chemotherapy. Bioorg. Med. Chem. 2006, 14, 5012-5019. [CrossRef] [PubMed]

84. Elsadek, B.; Graeser, R.; Esser, N.; Schäfer-Obodozie, C.; Ajaj, K.A.; Unger, C.; Warnecke, A.; Saleem, T.; El-Melegy, N.; Madkor, H.; et al. Development of a novel prodrug of paclitaxel that is cleaved by prostate-specific antigen: An in vitro and in vivo evaluation study. Eur. J. Cancer 2010, 46, 3434-3444. [CrossRef] [PubMed]

85. Kumar, S.K.; Williams, S.A.; Isaacs, J.T.; Denmeade, S.R.; Khan, S.R. Modulating paclitaxel bioavailability for targeting prostate cancer. Bioorg. Med. Chem. 2007, 15, 4973-4984. [CrossRef] [PubMed]

86. De Groot, F.M.H.; Van Berkom, L.W.A.; Scheeren, H.W. Synthesis and biological evaluation of $2^{\prime}$-carbamate-linked and 2'-carbonate-linked prodrugs of paclitaxel selective activation by the tumor-associated protease plasmin. J. Med. Chem. 2000, 43, 3093-3102. [CrossRef] [PubMed]

87. Liu, D.Z.; Sinchaikul, S.; Reddy, P.V.G.; Chang, M.Y.; Chen, S.T. Synthesis of 2'-paclitaxel methyl 2-glucopyranosyl succinate for specific targeted delivery to cancer cells. Bioorg. Med. Chem. Lett. 2007, 17, 617-620. [CrossRef] [PubMed]

88. Lin, Y.-S.; Tungpradit, R.; Sinchaikul, S.; An, F.-M.; Liu, D.-Z.; Phutrakul, S.; Chen, S.-T. Targeting the delivery of glycan-based paclitaxel prodrugs to cancer cells via glucose transporters. J. Med. Chem. 2008, 51, 7428-7441. [CrossRef] [PubMed]

89. Strese, S.; Fryknäs, M.; Larsson, R.; Gullbo, J. Effects of hypoxia on human cancer cell line chemosensitivity. BMC Cancer 2013, 13, 331. [CrossRef] [PubMed]

90. Pilkington-Miksa, M.; Arosio, D.; Battistini, L.; Belvisi, L.; de Matteo, M.; Vasile, F.; Burreddu, P.; Carta, P.; Rassu, G.; Perego, P.; et al. Design, synthesis, and biological evaluation of novel cRGD-paclitaxel conjugates for integrin-assisted drug delivery. Bioconjug. Chem. 2012, 23, 1610-1622. [CrossRef] [PubMed]

91. Zhang, P.; Hu, L.; Yin, Q.; Feng, L.; Li, Y. Transferrin-modified c[RGDfK]-paclitaxel loaded hybrid micelle for sequential blood-brain barrier penetration and glioma targeting therapy. Mol. Pharm. 2012, 9, 1590-1598. [CrossRef] [PubMed]

92. Colombo, R.; Mingozzi, M.; Belvisi, L.; Arosio, D.; Carenini, N.; Perego, P.; Zaffaroni, N.; Cesare, D.; Castiglioni, V.; Scanziani, E.; et al. Synthesis and biological evaluation (in vitro and in vivo) of cyclic RGD peptidomimetic-Paclitaxel conjugates targeting integrin $\alpha \mathrm{V} \beta_{3}$. J. Med. Chem. 2012, 55, 10460-10474. [CrossRef] [PubMed]

93. Chen, X.; Plasencia, C.; Hou, Y.; Neamati, N. Synthesis and biological evaluation of dimeric RGD peptide-paclitaxel conjugate as a model for integrin-targeted drug delivery. J. Med. Chem. 2005, 48, 1098-1106. [CrossRef] [PubMed]

94. Shan, L.; Liu, M.; Wu, C.; Zhao, L.; Li, S.; Xu, L.; Cao, W.; Gao, G.; Gu, Y. Multi-small molecule conjugations as new targeted delivery carriers for tumor therapy. Int. J. Nanomed. 2015, 10, 5571-5591. [CrossRef] [PubMed]

95. Ndungu, J.M.; Lu, Y.J.; Zhu, S.; Yang, C.; Wang, X.; Chen, G.; Shin, D.M.; Snyder, J.P.; Shoji, M.; Sun, A. Targeted delivery of paclitaxel to tumor cells: Synthesis and in vitro evaluation. J. Med. Chem. 2010, 53, 3127-3132. [CrossRef] [PubMed] 
96. Gund, M.; Khanna, A.; Dubash, N.; Damre, A.; Singh, K.S.; Satyam, A. Water-soluble prodrugs of paclitaxel containing self-immolative disulfide linkers. Bioorg. Med. Chem. Lett. 2015, 25, 122-127. [CrossRef] [PubMed]

97. Vrudhula, V.M.; Kerr, D.E.; Siemers, N.O.; Dubowchik, G.M.; Senter, P.D. Cephalosporin prodrugs of paclitaxel for immunologically specific activation by L-49-sFv- $\beta$-Lactamase fusion protein. Bioorg. Med. Chem. Lett. 2003, 13, 539-542. [CrossRef]

98. De Bont, D.B.; Leenders, R.G.; Haisma, H.J.; van der Meulen-Muileman, I.; Scheeren, H.W. Synthesis and biological activity of $\beta$-glucuronyl carbamate-based prodrugs of paclitaxel as potential candidates for ADEPT. Bioorg. Med. Chem. 1997, 5, 405-414. [CrossRef]

99. Ishida, D.; Nawa, A.; Tanino, T.; Goshima, F.; Luo, C.H.; Iwaki, M.; Kajiyama, H.; Shibata, K.; Yamamoto, E.; Ino, K.; et al. Enhanced cytotoxicity with a novel system combining the paclitaxel-2'-ethylcarbonate prodrug and an HSV amplicon with an attenuated replication-competent virus, HF10 as a helper virus. Cancer Lett. 2010, 288, 17-27. [CrossRef] [PubMed]

100. Li, Y.-C.; Rissanen, S.; Stepniewski, M.; Cramariuc, O.; Róg, T.; Mirza, S.; Xhaard, H.; Wytrwal, M.; Kepczynski, M.; Bunker, A. Study of interaction between PEG carrier and three relevant drug molecules: Piroxicam, paclitaxel, and hematoporphyrin. J. Phys. Chem. B 2012, 116, 7334-7341. [CrossRef] [PubMed]

101. Feng, X.; Yuan, Y.J.; Wu, J.C. Synthesis and evaluation of water-soluble paclitaxel prodrugs. Bioorg. Med. Chem. Lett. 2002, 12, 3301-3303. [CrossRef]

102. Greenwald, R.B.; Gilbert, C.W.; Pendri, A.; Conover, C.D.; Xia, J.; Martinez, A. Drug delivery systems: Water soluble taxol 2'-poly(ethylene glycol) ester prodrugs-design and in vivo effectiveness. J. Med. Chem. 1996, 39, 424-431. [CrossRef] [PubMed]

103. Liang, L.; Lin, S.W.; Dai, W.; Lu, J.K.; Yang, T.Y.; Xiang, Y.; Zhang, Y.; Li, R.T.; Zhang, Q. Novel cathepsin B-sensitive paclitaxel conjugate: Higher water solubility, better efficacy and lower toxicity. J. Control. Release 2012, 160, 618-629. [CrossRef] [PubMed]

104. Gu, Y.; Zhong, Y.; Meng, F.; Cheng, R.; Deng, C.; Zhong, Z. Acetal-linked paclitaxel prodrug micellar nanoparticles as a versatile and potent platform for cancer therapy. Biomacromolecules 2013, 14, 2772-2780. [CrossRef] [PubMed]

105. Yu, Y.; Zou, J.; Yu, L.; Ji, W.; Li, Y.; Law, W.; Cheng, C. Functional polylactide-g-paclitaxel-poly(ethylene glycol) by azide-alkyne click chemistry. Macromolecules 2011, 44, 4793-4800. [CrossRef]

106. Lv, S.; Tang, Z.; Zhang, D.; Song, W.; Li, M.; Lin, J.; Liu, H.; Chen, X. Well-defined polymer-drug conjugate engineered with redox and $\mathrm{pH}$-sensitive release mechanism for efficient delivery of paclitaxel. J. Control. Release 2014, 194, 220-227. [CrossRef] [PubMed]

107. Chen, W.; Shi, Y.; Feng, H.; Du, M.; Zhang, J.Z.; Hu, J.; Yang, D. Preparation of copolymer paclitaxel covalently linked via a disulfide bond and its application on controlled drug delivery. J. Phys. Chem. B 2012, 116, 9231-9237. [CrossRef] [PubMed]

108. Zhu, L.; Wang, T.; Perche, F.; Taigind, A.; Torchilin, V.P. Enhanced anticancer activity of nanopreparation containing an MMP2-sensitive PEG-drug conjugate and cell-penetrating moiety. Proc. Natl. Acad. Sci. USA 2013, 110, 17047-17052. [CrossRef] [PubMed]

109. Bao, Y.; Guo, Y.; Zhuang, X.; Li, D.; Cheng, B.; Tan, S.; Zhang, Z. Polyethylene glycol succinate-based redox-sensitive paclitaxel prodrug for overcoming multidrug resistance in cancer cells $\mathrm{D}$ - $\alpha$-tocopherol. Mol. Pharm. 2014, 11, 3196-3209. [CrossRef] [PubMed]

110. Safavy, A.; Raisch, K.P.; Khazaeli, M.B.; Buchsbaum, D.J.; Bonner, J.A. Paclitaxel derivatives for targeted therapy of cancer: Toward the development of smart taxanes. J. Med. Chem. 1999, 42, 4919-4924. [CrossRef] [PubMed]

111. Safavy, A.; Raisch, K.P.; Matusiak, D.; Bhatnagar, S.; Helson, L. Single-drug multiligand conjugates: Synthesis and preliminary cytotoxicity evaluation of a paclitaxel-dipeptide "scorpion" molecule. Bioconjug. Chem. 2006, 17, 565-570. [CrossRef] [PubMed]

112. Yin, T.; Wu, Q.; Wang, L.; Yin, L.; Zhou, J.; Huo, M. Well-defined redox-sensitive polyethene glycol-paclitaxel prodrug conjugate for tumor-specific delivery of paclitaxel using octreotide for tumor targeting. Mol. Pharm. 2015, 12, 3020-3031. [CrossRef] [PubMed]

113. Yin, D.; Ge, Z.; Yang, W.; Liu, C.; Yuan, Y. Inhibition of tumor metastasis in vivo by combination of paclitaxel and hyaluronic acid. Cancer Lett. 2006, 243, 71-79. [CrossRef] [PubMed]

114. Lee, H.; Lee, K.; Tae, G.P. Hyaluronic acid-paclitaxel conjugate micelles: Synthesis, characterization, and antitumor activity. Bioconjug. Chem. 2008, 19, 1319-1325. [CrossRef] [PubMed] 
115. Yin, S.; Huai, J.; Chen, X.; Yang, Y.; Zhang, X.; Gan, Y.; Wang, G.; Gu, X.; Li, J. Intracellular delivery and antitumor effects of a redox-responsive polymeric paclitaxel conjugate based on hyaluronic acid. Acta Biomater. 2015, 26, 274-285. [CrossRef] [PubMed]

116. Miller, K.; Eldar-Boock, A.; Polyak, D.; Segal, E.; Benayoun, L.; Shaked, Y.; Satchi-Fainaro, R. Antiangiogenic antitumor activity of HPMA copolymer-paclitaxel-alendronate conjugate on breast cancer bone metastasis mouse model. Mol. Pharm. 2011, 8, 1052-1062. [CrossRef] [PubMed]

117. Erez, R.; Segal, E.; Miller, K.; Satchi-Fainaro, R.; Shabat, D. Enhanced cytotoxicity of a polymer-drug conjugate with triple payload of paclitaxel. Bioorg. Med. Chem. 2009, 17, 4327-4335. [CrossRef] [PubMed]

118. Etrych, T.; Šírovaé, M.; Starovoytova, L.; Řiéhovaé, B.; Ulbrich, K. HPMA copolymer conjugates of paclitaxel and docetaxel with pH-controlled drug release. Mol. Pharm. 2010, 7, 1015-1026. [CrossRef] [PubMed]

119. Cline, E.N.; Li, M.-H.; Choi, S.K.; Herbstman, J.F.; Kaul, N.; Meyhöfer, E.; Skiniotis, G.; Baker, J.R.; Larson, R.G.; Walter, N.G. Paclitaxel-conjugated PAMAM dendrimers adversely affect microtubule structure through two independent modes of action. Biomacromolecules 2013, 14, 654-664. [CrossRef] [PubMed]

120. Lim, J.; Chouai, A.; Lo, S.-T.; Liu, W.; Sun, X.; Simanek, E.E. Design, synthesis, characterization, and biological evaluation of triazine dendrimers bearing paclitaxel using ester and ester/disulfide linkages. Bioconjug. Chem. 2009, 20, 2154-2161. [CrossRef] [PubMed]

121. Lim, J.; Lo, S.T.; Hill, S.; Pavan, G.M.; Sun, X.K.; Simanek, E.E. Antitumor activity and molecular dynamics simulations of paclitaxel-laden triazine dendrimers. Mol. Pharm. 2012, 9, 404-412. [CrossRef] [PubMed]

122. Lim, J.; Simanek, E.E. Synthesis of water-soluble dendrimers based on melamine bearing 16 paclitaxel groups. Org. Lett. 2008, 10, 201-204. [CrossRef] [PubMed]

123. Lee, C.; Lo, S.-T.; Lim, J.; da Costa, V.C.P.; Ramezani, S.; Öz, O.K.; Pavan, G.M.; Annunziata, O.; Sun, X.; Simanek, E.E. Design, synthesis and biological assessment of a triazine dendrimer with approximately 16 Paclitaxel groups and 8 PEG groups. Mol. Pharm. 2013, 10, 4452-4461. [CrossRef] [PubMed]

124. Kala, S.; Mak, A.S.C.; Liu, X.; Posocco, P.; Pricl, S.; Peng, L.; Wong, A.S.T. Combination of dendrimernanovector-mediated small interfering RNA delivery to target Akt with the clinical anticancer drug paclitaxel for effective and potent anticancer activity in treating ovarian cancer. J. Med. Chem. 2014, 57, 2634-2642. [CrossRef] [PubMed]

125. Satsangi, A.; Roy, S.S.; Satsangi, R.K.; Vadlamudi, R.K.; Ong, J.L. Design of a paclitaxel prodrug conjugate for active targeting of an enzyme upregulated in breast cancer cells. Mol. Pharm. 2014, 11, 1906-1918. [CrossRef] [PubMed]

126. Clementi, C.; Miller, K.; Mero, A.; Satchi-Fainaro, R.; Pasut, G. Dendritic poly(ethylene glycol) bearing paclitaxel and alendronate for targeting bone neoplasms. Mol. Pharm. 2011, 8, 1063-1072. [CrossRef] [PubMed]

127. Lee, E.; Lee, J.; Lee, I.H.; Yu, M.; Kim, H.; Chae, S.Y.; Jon, S. Conjugated chitosan as a novel platform for oral delivery of paclitaxel. J. Med. Chem. 2008, 51, 6442-6449. [CrossRef] [PubMed]

128. Liebmann, J.E.; Cook, J.A.; Lipschultz, C.; Teague, D.; Fisher, J.; Mitchell, J.B. Cytotoxic studies of paclitaxel (Taxol) in human tumour cell lines. Br. J. Cancer 1993, 68, 1104-1109. [CrossRef] [PubMed]

129. Cavallaro, G.; Licciardi, M.; Caliceti, P.; Salmaso, S.; Giammona, G. Synthesis, physico-chemical and biological characterization of a paclitaxel macromolecular prodrug. Eur. J. Pharm. Biopharm. 2004, 58, 151-159. [CrossRef] [PubMed]

130. Yu, Y.; Chen, C.; Law, W.; Mok, J.; Zou, J.; Prasad, P.N.; Cheng, C. Well-defined degradable brush polymer-drug conjugates for sustained delivery of paclitaxel. Mol. Pharm. 2013, 10, 867-874. [CrossRef] [PubMed]

131. Dalela, M.; Shrivastav, T.G.; Kharbanda, S.; Singh, H. pH-sensitive biocompatible nanoparticles of paclitaxel-conjugated poly(styrene-co- maleic acid) for anticancer drug delivery in solid tumor of syngeneic mice. ACS Appl. Mater. Interfaces 2015, 7, 26530-26548. [CrossRef] [PubMed]

132. Wang, Y.; Xin, D.; Liu, K.; Zhu, M.; Xiang, J. Heparin-Paclitaxel Conjugates as Drug Delivery System: Synthesis, Self-Assembly Property, Drug Release, and Antitumor Activity. Bioconjug. Chem. 2009, 20, 2214-2221. [CrossRef] [PubMed]

133. Dosio, F.; Brusa, P.; Crosasso, P.; Arpicco, S.; Cattel, L. Preparation, characterization and properties in vitro and in vivo of a paclitaxel-albumin conjugate. J. Control. Release 1997, 47, 293-304. [CrossRef] 
134. Safavy, A.; Bonner, J.A.; Waksal, H.W.; Buchsbaum, D.J.; Gillespie, G.Y.; Khazaeli, M.B.; Arani, R.; Chen, D.T.; Carpenter, M.; Raisch, K.P. Synthesis and biological evaluation of paclitaxel-C225 conjugate as a model for targeted drug delivery. Bioconjug. Chem. 2003, 14, 302-310. [CrossRef] [PubMed]

135. Yuan, L.; Chen, W.; Hu, J.; Zhang, J.Z.; Yang, D. Mechanistic study of the covalent loading of paclitaxel via disulfide linkers for controlled drug release. Langmuir 2013, 29, 734-743. [CrossRef] [PubMed]

136. Lai, C.-H.; Chang, T.-C.; Chuang, Y.-J.; Tzou, D.-L.; Lin, C.-C. Stepwise orthogonal click chemistry toward fabrication of paclitaxel/galactose functionalized fluorescent nanoparticles for HepG2 cell targeting and delivery. Bioconjug. Chem. 2013, 24, 1698-1709. [CrossRef] [PubMed]

137. Ding, Y.; Zhou, Y.-Y.; Chen, H.; Geng, D.-D.; Wu, D.-Y.; Hong, J.; Shen, W.-B.; Hang, T.-J.; Zhang, C. The performance of thiol-terminated PEG-paclitaxel-conjugated gold nanoparticles. Biomaterials 2013, 34, 10217-10227. [CrossRef] [PubMed]

138. Gibson, J.D.; Khanal, B.P.; Zubarev, E.R. Paclitaxel-functionalized gold nanoparticles. J. Am. Chem. Soc. 2007, 129, 11653-11661. [CrossRef] [PubMed]

139. Xu, Z.; Zhu, S.; Wang, M.; Li, Y.; Shi, P.; Huang, X. Delivery of paclitaxel using PEGylated graphene oxide as a nanocarrier. ACS Appl. Mater. Interfaces 2015, 7, 1355-1363. [CrossRef] [PubMed]

140. Zakharian, T.Y.; Seryshev, A.; Sitharaman, B.; Gilbert, B.E.; Knight, V.; Wilson, L.J. A fullerene-paclitaxel chemotherapeutic: Synthesis, characterization, and study of biological activity in tissue culture. J. Am. Chem. Soc. 2005, 127, 12508-12509. [CrossRef] [PubMed]

(C) 2016 by the authors; licensee MDPI, Basel, Switzerland. This article is an open access article distributed under the terms and conditions of the Creative Commons Attribution (CC-BY) license (http://creativecommons.org/licenses/by/4.0/). 